\title{
Geochronology, geochemistry and tectonic significance of three-phase Jurassic-Cretaceous volcanic rocks in the east of southeast China
}

\author{
XINQI YU ${ }^{1}$, XiU LiU ${ }^{1}$, Ziwei Chen ${ }^{1}$, MENGYAN LiU ${ }^{1}$ \\ ${ }^{1}$ School of Earth Sciences and Resources, China University \\ of Geosciences, Beijing 100083, China
}

Three volcanic rock layers are distributed within the Jurassic-Cretaceous strata in the junction region of Zhejiang, Jiangxi, and Anhui Provinces in the east of Southeast China. This study obtains the LA-ICP-MS U-Pb zircon $(\mathrm{Th} / \mathrm{U}$ ratios $>0.15$ ) with ages $154.7 \pm 2.5 \mathrm{Ma}$ and $139-134 \mathrm{Ma}$ for rhyolites from the lower-layer (plus ignimbrite) and middlelayer rhyolites, respectively. Moreover, the SHRIMP zircon $\mathrm{U}-\mathrm{Th}-\mathrm{Pb}$ analytical results show that a weighted ${ }^{206} \mathrm{~Pb} /{ }^{238} \mathrm{U}$ average of $99.0 \pm 0.7 \mathrm{Ma}$ for the upper basalt layer.

The lower rhyolite layer has relatively low $\mathrm{SiO}_{2}$ and high $\mathrm{Al}_{2} \mathrm{O}_{3}$ contents, and shows an enrichment of large ion lithophile elements and depletion of high field strength elements. This layer is strongly enriched in LREE and depleted in HREEs, with weakly negative Eu anomalies. By contrast, the middle rhyolite layer is characterized by high $\mathrm{SiO}_{2}$ and low $\mathrm{Al}_{2} \mathrm{O}_{3}$ contents. This layer has typical wingshaped rare earth element distribution patterns with negative $\mathrm{Eu}$ anomalies. The late period basalt, which is plotted within the alkaline series field in the $\mathrm{SiO}_{2}-\left(\mathrm{K}_{2} \mathrm{O}+\mathrm{Na}_{2} \mathrm{O}\right)$ and $\mathrm{Nb} / \mathrm{Y}-$ $\mathrm{Zr} / \mathrm{TiO}_{2}$ diagrams, displays the characteristics of the alkaline series. The values are provided in the tholeiitic basaltic rock field in the $\mathrm{TFeO} / \mathrm{MgO}-\mathrm{SiO}_{2}$ diagram. Therefore, the basalt belongs to the typical alkaline olivine basalt. Alkali olivine basalt with low $\mathrm{Nb} / \mathrm{Th}$ and $\mathrm{Ti} / \mathrm{Yb}$ values (i.e., $\mathrm{Nb} / \mathrm{Th}=2.21-$ 4.98 (3.43 on average); $\mathrm{Ti} / \mathrm{Yb}=3125-5753$ (3975 on average)) and high $\mathrm{Nb} / \mathrm{U}$ value (i.e., $\mathrm{Nb} / \mathrm{U}=6.63-25.82$ (16d 24 on average)) indicates that alkaline olivine basalt contributes to the crustal material.

The lower layer rhyolite behaves similar to the S-/A-type rocks and the upper layer has affinity to A-type rocks, thereby implying an extension environment. Overall, igneous rocks evolved from high $\mathrm{Sr}-$ low $\mathrm{Yb}$ to low $\mathrm{Sr}$-high $\mathrm{Yb}$, which may reflect the evolution of the tectonic setting from the subduction to the lithospheric extension setting during the early Cretaceous (ca. $142 \pm 3 \mathrm{Ma}$ ). After a relatively quiet period, the lithospheric extension acts intensely and causes the effusing of basaltic lava at approximately 99 Ma during the middle Cretaceous.

* Financially supported by the NSFC (No 41872201). 